\title{
Practical theological perspectives on preaching to listeners experiencing angst or nothingness within the present reality of a post-pandemic world
}

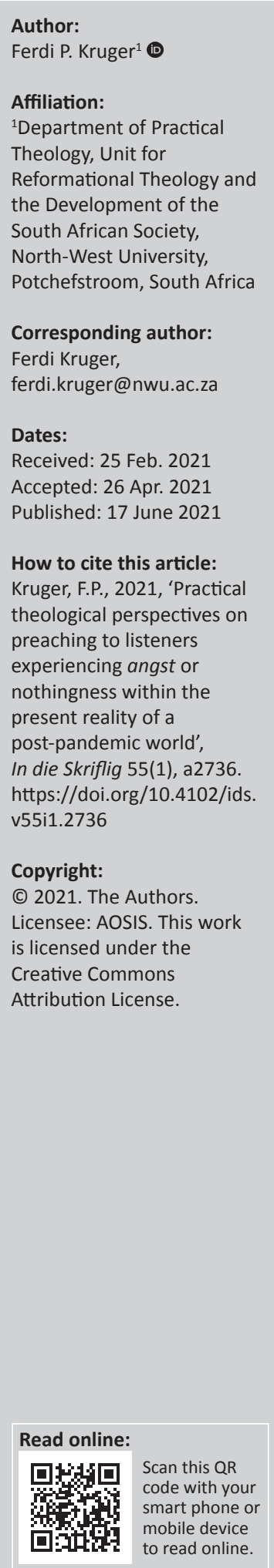

After conducting a literature search, the purpose of this article has emerged. The essential elements of a homiletical praxis, interested in dealing with the gospel, are related to the concrete circumstances of listeners. Consequently, the feelings of angst or nothingness that listeners experience in a post-pandemic world are now integrated into the reflection of a homiletical praxis. A homiletical praxis should not fall into the trap of trying to discern the signs of the times in a one-sided manner and an over-simplifying way, but should rather help listeners to understand the essence of hope. The dimensions of yet and not yet, that enable listeners to understand the idea of hope against hope, could be functional in identifying the objective of this research. The research problem is as follows: What kind of practical theological perspectives could be delineated for a praxeology of preaching to offer insight to listeners experiencing angst and a feeling of nothingness within a post-pandemic world? The problem addressed in this article inevitably takes cognisance of the listeners' experiences of reality caused by the effects of the COVID-19 pandemic. A profound quest for a homiletical praxis in which life is central has also emerged in the research. Eventually, this research indicates the contours for a praxis that views preaching with clairvoyant eyes for listeners' concrete experiences. I discovered that preaching offers the opportunity to approach disorienting dilemmas that evoke intriguing self-reflection to answer the question: Where do we go from here? A homiletical praxeology, therefore, also has to deal with the experiences of listeners. To address this research question, the notion of critical correlation offers a methodological framework for operating within. It allows the researcher to set up a dialogue between questions related to the homiletical praxis on the one hand, and perspectives that come forth in reflecting the reality of the COVID-19 pandemic on the other. A second phase involves providing a theological perspective on God who can perform new deeds amidst the unusual. Deliberating on this will pave the way for a homiletical theory at the end of the article.

Contribution: This article aims to engage with the basic tenet of preaching, viewed from a Reformational paradigm and wants to contribute towards a better understanding of a homiletical praxeology within a post-pandemic world.

Keywords: post-pandemic; angst; nothingness; liveable life; remembrance.

\section{Introduction}

'What time is it, Mr Wolf?' This question is called and responded to within a familiar children's game. At a certain time in this game, 'Mr Wolf' will start chasing the children to find another one to replace him or her. In 1972, two microbiologists, Burnet and White, predicted the emergence of a new infectious disease in the near future. People could not understand the logic of their prediction. For the span of 49 years, it is as though people have chanted 'What time is it, $\mathrm{Mr}$ Wolf'? The scientists' prediction seemed to be an unfulfilled prophecy (Dein 2020:3). But, similar to the children's game, the decisive time for children to run is when they hear the words 'It is lunchtime' - and this arrived in 2020. However, the COVID-19 pandemic is not a game played by people at a party, and it is certainly not something to enjoy. Important changes in the normal course of life have urged people to guess about what the 'new normal' would then be in future. People even speculate whether this pandemic should be considered as an eschatological sign of the second coming of Christ (Jones 2020:2).

Preachers certainly are not able to escape the strange reality that is allegedly referred to as the 'new normal' and are, themselves, earnestly seeking for ways to engage listeners within the unusual reality of a post-pandemic world (Sancken 2019:2). In their recent research, Steyn, 
Wepener \& Pieterse (2020:10) have offered an interesting perspective on how this pandemic has disrupted people's lives. The idea of being disrupted by living far away from people and of things that have always provided you with the notion of feeling safe, is underlined. The importance of being a close community that should be visible in daily life is jeopardised to some extent.

Limited opportunities to worship within a closed community of believers has challenged faith communities with a myriad of aspects to consider about the liturgical-spatial dimensions of preaching. One of the immediate concerns about a praxis of living far away from people is the difficulty of adhering to love for your fellow being which implies keeping a safe distance between yourself and them. The virtual reality people are exposed to, seems to be contradictory to the previous normal reality where physical proximity and contact were integral parts of a praxis.

The profound need for fraternity and fellowship should be examined against this background. In addition to this, the reality of seeing the outside world, and regarding reality outside our homes as dangerous will certainly offer challenges to faith communities. Is it possible at all to preach to listeners about their responsibility within society at a time when the emphasis falls on love for another by keeping your distance? Therefore, one must reflect on how preaching could help reframe listeners' experiences of the COVID-19 pandemic into a meaningful and coherent whole where a virtual world and real world are meeting each other. As familiar activities, preaching and liturgy are, to my mind, among those aimed at finding appropriate words to bring the gospel and the complexity of what listeners experience into an enlightening and penetrating dialogue. A meaningful utilisation of the online presence with a close interrelationship with the off-line presence must be integrated within our homiletical approach to the new normal.

Preaching and liturgy must help participating listeners in their attempt to faithfully see what the meaning of life in a new normal has to entail (Louw 2016:7). This further entails emphasis on the idea of preaching that is a purposeful act of signification (Steinmeijer 2011:255). As the significance of preaching lies in voicing the living voice of the gospel, it has the intention to reframe listeners' experiences in order for them to experience the integration of a considerable number of aspects in their lives. It is evident that life, as such, is a prominent aspect in this process of signification which refers to the need of preaching aspects related to life communicated by the gospel (Lauster 2007:143; Louw 2016: 8).

In a homiletical praxis, conflicting feelings should be considered of listeners who have to struggle with the reality of isolation amidst exposure to the uncertainty that COVID-19 regulations bring about. This increasing awareness of impotence that results from the distorted outlook of an immutable Christian future is part and parcel of the field of tension caused by life in a post-pandemic world (Beach 1999:91). In the first article that has addressed the idea of preaching to postmodernist post-COVID-19 listeners, the importance of cognition, as a process to make sense of what is happening in life, was discussed (Fiske 2004:133). The underlying importance of this situation for preaching, propels us to highlight the presupposition that life is about more than crossing your arms to wait for the inevitable to occur. The importance of a liveable life and how we could embrace this idea within the practice of our immediate environment, inevitably, comes into play.

As mentioned, COVID-19 has undeniably thrown the world into a state of fear and chaos that puts people under considerable pressure (Jones 2020:3). The philosopher, Marten Heidegger, once emphasised the notion of angst that relates to a feeling or mood (Gefühl), which indicates an encounter with nothing or nothingness (Pembroke 2013:13). In and through the experience of angst, a person, in fact, is confronted with the feeling of losing their grip on relationships, workplaces and daily life. An all-pervasive feeling of dread or anxiety arises when the world that is usually experienced as a safe space, associated with a familiar and comfortable lifestyle, suddenly begins to feel strangely unsettling and even alien. Heidegger helps us to understand that persons gripped by angst, feels disconnected or estranged from the world they are living in.

This leads us to the formulation of the research question in this article: What kind of practical theological perspectives could be expressed in a praxeology of preaching to offer insight to listeners experiencing angst and a feeling of nothingness within a post-pandemic world? To address this question, the notion of critical correlation, as proposed by Ballard and Pritchard (2006:63), offers a methodological framework to operate within. It allows the researcher to first set up a dialogue between questions related to the homiletical praxis on the one hand, and perspectives that come forth in the reflection about the reality of the COVID-19 pandemic on the other. A second phase involves providing a theological perspective on God who can perform new deeds amidst the unusual and, deliberating on this, will pave the way for a homiletical theory at the end of the article.

\section{Dialogue between descriptive perspectives of the COVID-19 pandemic and a homiletic praxis searching for a new mind-set}

When it comes to a hermeneutical dialogue between the various phases of this investigation, one must start by admitting one's own discomfort with some of the familiar theological vocabulary, mainly because of the fact that the pandemic has shaken the safe spaces in our conceptualisations of the liturgical-spatial nature of preaching. The new way of being in the world and of being separated from a community of believers, involves, for example, some of the aspects to be dealt with in this dialogue in the face of this discomfort. Immink (2019), a much discussed homiletic scholar, announces, for instance, the intriguing arrangement where: 
The preaching practice is rooted in a reciprocity between the gathered community and the preacher. There would be no preaching without a gathered community and without the interaction between the community and the preacher. (p. 13)

The reality of a lockdown and of social distancing persuades one to revisit the general accepted principles as underlined by Immink in this instance. Theory and practice again find themselves in a field of tension that calls on acute reflection on communication as provided by preaching in a time of uncertainty.

\section{Terminological uncertainty? A post-pandemic world or rather an unfixed post-pandemic world shaded by the 'yet' but 'not yet'?}

According to Rosenberg (1998:7), epidemics and pandemics unfold as social dramas and in the sequence of three acts. The earliest signs of a pandemic are subtle. Whether influenced by a desire for self-reassurance or a need to protect economic interests, citizens ignore signs that something is awry until the acceleration of illness and deaths forces reluctant acknowledgement (Jones 2020:3). Recognition of the seriousness of an epidemic launches the second act in which people demand and offer mechanistic and moral explanations. The explanations, in turn, generate public responses and further increase feelings of fear and uncertainty. These fears can make the third act as dramatic and disruptive as the disease itself. Pandemics will eventually resolve, whether by succumbing to societal action (reaction) or whether the number of susceptible victims has been depleted. As Rosenberg puts it:

Epidemics start at a moment in time, proceed on a stage limited in space and duration, follow a plot line of increasing revelatory tension, move to a crisis of individual and collective character, then drift toward closure. (Rosenburg 1998:6)

This drama has been playing out around COVID-19; first in China and now in many countries worldwide (Jones 2020:2).

The post-pandemic world and with its awareness that the outbreak of the coronavirus has already influenced people's lives deeply during 2020 is pivotal in my interpretation. It should, however, also be acknowledged that the threat of the virus is not something of the past and will still be a reality for years to come (Taylor et al. 2020:17). Even within the context of speaking about a post-pandemic world, manifestations of new variants of this virus will remain a threat for people in all age groups. People in all age groups are increasingly alerted to take prudent steps to protect themselves. Whether we are still swimming against the power of the storm of the pandemic or whether we can already speak of a post-pandemic world after vaccination will soon become known, but this is not the matter to be examined in this article. It is probably more suitable to speak of a liminal situation, of neither here nor there, in which the pandemic has unsettled the familiar or the normal, instead of insisting on a post-pandemic world (Wepener 2012:295).
When and if the current pandemic comes to an end, several factors would most probably have coloured most people's experiences of their lives being derailed, including the following aspects:

- Most people can admit that they are touched by the loss of friends and loved ones. In the pandemic they have been forced to observe the last moments of their loved ones from a distance or through a window, and even funerals have become an event attended by people behind masks.

- The culture and environment at work have changed due to an online mode of functioning. A strange world of conversing with people via a computer has become general practice, and a question rises regarding the sustainability of this kind of custom.

- For a considerable number of people, the loss of jobs and foreclosures on homes have become a reality.

- There is an underlying fear of trusting people when infection may occur, and this is a challenge.

- Relationships that have been negatively influenced by social distancing and self-isolation could disintegrate.

- The functioning of post-traumatic stress disorders will inevitably pose challenges.

- The struggles of people are trapped in houses and subjected to abusive and coercive relationships will most probably intensify (cf. Taylor 2019:5-8 for his intriguing description of this phenomenon).

People are already mentioning the notion of a COVID-stress syndrome as one of the results of the pandemic.

This syndrome is characterised by an exaggerated fear of being infected, anxiety about touching surfaces, as well as concerns about strangers who might be infectious (Taylor et al. 2020:9). High levels of anxiety about personal health and regular checking (testing) to determine if everything is normal, could also occur. The question whether this unease is only about adjustment, self-protection, or a chronic syndrome which makes people reluctant to leave the safe environment of their homes, should still be further investigated (Bowker et al. 2019:218). Much could be said in favour of these ideas, as well as against it, but fear and uncertainty are indeed part of daily life. Acknowledgement of the feelings of nothingness is important, as well as a focus on a renewed commitment to their existence in unusual circumstances as discussed in the subsequent section.

\section{Preaching as guidance to find meaning in disorientating dilemmas}

Preaching within a post-pandemic world could benefit from revisiting the idea of Helfen Zum Leben [life-support] aimed at guiding listeners to cope with the demands of their daily lives (Grethlein 2012:16). The need for finding hope and meaning through preaching within the new normal of life should be evident. In the present section, the emphasis is on the fact that meaning identification (Sinndeutung) within a post-pandemic world will most probably be a gruelling process and must be seen as a 
cornerstone of the present reflection. Preaching is after all aimed at guiding listeners to discern the meaningfulness of life, even if they have feelings of nothingness. Here, Mezirow's educationally constructed theory on how learners could validate the meaning of their experiences, is valuable in the present description of the problematic praxis caused by the effects of the COVID-19 pandemic. Mezirow (1995:13-15) emphasises the following sequences in which people try to understand the meaning of what they are experiencing:

- A disorienting dilemma emerges that offers challenges to people who suffer from its effects.

- Based on the dilemma, self-examination or -taxation about things that could add value in life is inevitable.

- The taxation process continues to include a critical assessment of the feelings of alienation before they can envision a meaningful life.

- People may be unable to relate to the experiences of others, because one is living in a vacuum.

- People then explore options for new ways of acting in all aspects of life.

- A creative phase of building confidence in a new way of behaving in the unusual circumstances follows.

- It is necessary to thoroughly plan a course of action because, without careful planning, people will experience life as unreal.

- People acquire new knowledge to implement plans for their lives.

- They eventually start experimenting with new roles in coping with the reality of unusual times.

- Lastly those who are transformed are reintegrated into society.

It seems that planned preaching within the reality of now and here, and with the purpose of building up, guidance, navigating and accompaniment of listeners in a postpandemic world, is not far removed from the sequence in this list. Critique could possibly be raised against Mezirow's insight by stating that, as disorienting dilemmas, pandemics do not always follow the same pattern of sequence, and more than one sequence could be experienced simultaneously. The importance of Mezirow's research is nonetheless that the emotions evoked by disorienting dilemmas are important building blocks for discerning the meaning of life.

The introduction above has asked where we go from here in a post-pandemic world. It has become clear that we have to admit that the answer to this question, working with the insights of Mezirow, is to see that what lies ahead is a journey and not a sprint. Mezirow (1995:14) assists in the realisation that a multitude of things should come to fruition. Furthermore, it is my firm belief that preaching should be regarded as a careful and purposeful process of gradually guiding listeners to determine the meaningfulness of life within a post-pandemic world. The argument here has therefore indicated two focal points that should be integrated in a homiletical praxeology: firstly, people live in angst today; and secondly, the concomitant opportunity to revisit the essential aspects of what makes life worthwhile in a post-pandemic world. This integration will be made towards the article's conclusion.

\section{The earnest quest for a homiletical praxis that deals with the realisation that the unusual is part of a holistic life}

Grözinger (2005:3) posits the apparently obvious idea that people's experiences relate to places and events. If places and events could create experiences, preaching must be described as the shaping of people's experiences, because it is delivered in certain places and within a particular time. The challenge within a post-pandemic world will be to find the appropriate words to identify people's experiences. Without a profound engagement with listeners' lives, preachers will struggle to achieve this. Brueggemann (2020:4) describes the contours of the challenge for preachers in a post-pandemic world when he suggests that what he calls the pandemic virus, actually embodies a summons to faith. He thus elicits the perception that listeners' faith lives offer a framework in which meaning could be determined. In his exact words, the COVID-19 pandemic is a subpoena that needs to be addressed in light of the gospel.

A homiletical praxeology directed at what listeners are experiencing in a post- pandemic world has to start with this kind of faith recognition, while keeping in mind that the God, proclaimed in sermons, does not stand apathetically to listeners' suffering. He is no spectator and observer of a post-pandemic world. It therefore makes complete sense that Brueggemann (2020:5) highlights the importance of the liturgical orientation of prayer even before mentioning the idea of preaching itself. The liturgical act of individual and communal prayer is, after all, based on the fact that it is no futile attempt at uttering words of nothingness. It is rather about communicating words of noteworthiness that intrinsically deal with many uncertainties. Prayer, after all, deals with the significance of life in the present, and therefore these days, when the pandemic evokes a sense of insignificance, the significance of prayer could not be ignored. It could also be said that prayer is an interrupting moment of silence within the routine of daily life, as well as a habitus for meaningfully communicating the deeper feelings and thoughts that arise from people's experiences of this pandemic. The notion of experiencing community within this act could not be overlooked. Earlier in this article, the idea of lamenting or of restraint was mentioned, and perhaps the notion of prayer as re-orientation should be highlighted as an integral part of a homiletical praxeology.

Based on the principle of becoming humble in God's presence, Brueggemann's vision (2020:79) of a new future (where do we go from here) in a post-pandemic world starts with his interpretation of Isaiah 43:19-20. 
Based on this exposition, Brueggemann claims that the pandemic could be seen as a kairos moment for realising that God can indeed do new things amidst the unusual, but he is adamant that God is calling believers to participate in this journey. In this life-journey, preaching must enable listeners not only to listen to sermons, but to envision opportunities to set up new signposts of God's compassion in a worthwhile life (cf. Nel 2018:61). Within the present, which is filled with angst experiences, there is indeed good news to be communicated. Consequently, preaching has to deal with the acknowledgement that we are not prisoners of this pandemic, but rather participants on the move in God's mission, which does not bypass current circumstances. The notion of a meaningful life provides us with the importance of becoming concrete beacons in the present day. Even around the imperative of social distancing, much could be done that could enable people to experience a worthwhile life.

The expression absence makes the heart grow fonder should prompt us towards a new understanding of the absence of people and places that will become dearer to us when they are absent. The love for other people in distancing yourself does have a flipside, namely finding creative ways to demonstrate care for people who are suffering from this pandemic.

By participating in this journey in a post-pandemic world, preaching must help listeners curb their expectations about life. The notion of the 'good old days' should be addressed by observing the importance of living in the present. An important phase in this process is to realise that this is now a time to remember the important aspects of life, but also to forget others. Atkins (2004:25), for example, posits that, at the heart of all worship, lies remembrance. Morrill (2001:67) prompts us to understand this kind of remembrance and underline that preaching about remembering the risen Christ must be restored in a coherent (re-member-ing) whole in the here and now of the listeners' lives in the post-pandemic world.

An integral part of this process of remembering (anamnesis) is to remind listeners of discerning what the practical relevance of their remembrances for the present entails. Remembrance of what God has done numerous times in their lives in the past should give guidance to the acknowledgement that he is present within the here and now. Arthurs (2018:13) confirms this very idea, namely that preaching could be seen as an act of stirring up listeners' memories in order for them to be confronted with present challenges, as well as giving them hope for the future, despite current experiences. An idea of Kandel (2006:116) dovetails with this as it reflects on people's memories, which actually enable them not only to recall important disorienting events in the past, but also to remember the exact emotions or feelings connoted by the particular event within the present. He (Kandel 2006: 116-117) continues in this vein, and indicates that remembrance is a mental time-travel journey that frees people from the constraints of time and of space.
In Ricoeur's understanding of remembrance, the following aspects are pivotal: Firstly, remembering is an act, because it is one's fidelity to the past (Ricoeur 2000:26). Secondly, Ricoeur speaks of the constructive framework of collective memory, which occurs when we remember experiences with other people while we are participating in sharing these memories with others. This exchange of memories reframes one's remembrances. Concrete and meaningful opportunities for listeners to share their memories of their experiences of the pandemic must be cultivated. In the event of sharing remembrances, meaning is created. Preaching that deals with remembrance could offer the invitation to share memories within smaller groups and invite others to share their memories. The power of sharing could not be ignored.

How do we go from here? By continuously remembering our vulnerability, as well as God's unique care for us. The importance of helping listeners to remember, is one thing, but the importance of helping them forget about other aspects, is a totally different matter. The emphasis of Ricoeur (2000:145) on what he described as happy forgetting, is valuable in this context. In remembering, we are recollecting experiences from the past and bringing them into present. Memories of the past are therefore reinterpreted or reexperienced in order to find new meaning (Ricoeur 2000:145). In the process of forgetting practices of the past that has centred on a life that was all about 'me', neglecting people who were suffering, something poignant is happening. The acts of remembering to remember and forgetting to forget then materialises. This kind of 'forgetting' is also a constructive way to remember injustices, and not forgetting about the possibility of repeating this (Ricoeur 2000:41).

\section{Theological perspectives on preaching to listeners in search for meaning identification on where we go from here}

In this section, two passages, namely Isaiah 43:18-19 and Romans 8:18-39, will be briefly discussed. Both passages deal with the profound question of where we go from here.

\section{Isaiah 43:18-19: Remember or forget?}

This passage indicates that memories of what God has done in the past indeed enjoy constructive or educational value, while no one should be bound to it (Motyer 1993:337). The reason for this is that the gospel gives proof of new dynamic ways in which God provides. Isaiah 40-55 deals with a unique time near the end of the Babylonian exile. This section starts with the words 'comfort, comfort, my people, says your God'. After many years of suffering, the exile has come to an end. The book of Isaiah is famous for the description of the faith crisis the Israelites experienced. Profound questions were raised as to whether the living God had abandoned his children. The rhetorical mood in the book of Isaiah has now shifted towards comfort and the promise of returning to the 
familiar place of Jerusalem, the normal place and circumstances in the past. In Isaiah 43:16-17, the memories of Israel have been refreshed or, one could also say, edited. In poetic terminology, the memory of the demise of Pharaoh's army is described. The image of the impossible entrance to freedom because of the waters of the sea that stood between Israel's freedom and the Egyptians come into distinct view (Otto 1983:33). It seems odd that Isaiah 43:18-19 advocates not remembering former things and not to consider old things. Isaiah is actually helping listeners to move ahead from focusing in a unilateral manner on the things of the past; which would have prevented dealing with the current circumstances (Otto 1983:14).

Applied to the contemporary post-pandemic world, it is evident that Christians could possibly succumb to the danger of remembering the wonderful things God had done in the past amidst previous epidemics and then forget that he could do new and wonderful things in the present. The danger of making too much of the past and too little of the present is imminent (Brueggemann 2018:97). One could say that life in the present reality of the exodus is described in Isaiah 43: 16-17. Therefore, the Israelites had to forget about certain things such as their rebellious conduct that caused the exile. They also had to forget of expecting God to utilise the same game-plan in order to redeem them. The Israelites had to be reminded of a God that will do a new thing, also described as a new exodus, in spite of their despondency (Brueggemann 1998:98). Vos (2007:27) helps us to see that the words utilised by Isaiah in verses 18-19 are actually the prophet's way of helping listeners understand that hope is like a lily that flowers in muddy water. This is the characteristic of profound hope, namely that it reminds us of our own frailty.

Therefore, hope grows in distressful and disorienting circumstances that evoke a multitude of memories. Viewed from the perspective of Isaiah 43, it seems imperative that preaching has to address the paradox of nothingness on the one hand, but not without the anchor of hope on the other; of new things that already is a work in progress. We have mentioned the idea of absence making the heart grow fonder. It seems like one could now argue that absence should make the heart remember. Therefore, hope is possible even in a hopeless situation filled with angst. These, then, are important findings around what occurs in the here and now without ignoring the significance of the future.

\section{Perspectives on Romans 8:18-39 calling listeners to a careful calculation}

The previous section has highlighted the idea of a new beginning under unusual circumstances. In this section, we are in search of a language that enables listeners to rename their experiences. Our starting point will be to acknowledge that, in biblical times, pandemics were not uncommon (Goldingay 2020:195). Although pandemics caused suffering to Christians in the past, they have also offered new avenues and new beginnings as described in the book of Ruth and in the narrative about Joseph's contribution to Egypt in a challenging time for the surrounding countries. Suffering has an element of determination or discernment at its essence. How else? If the pandemic reminds people of their fragility, it is inevitable that meaning rises from the experience of nothingness.

The work of Du Toit (2008:109) dovetails with this argument and points to one of the benefits of suffering, namely an opportunity to long for the future. He is adamant that this does not involve an attempt to escape the current circumstances, but a longing that not arises from our experiences. This longing is also not a vaccine or tranquiliser offered to what is experienced. Du Toit identifies an intense longing for the future that has already arrived, but not yet in full. This insight into what the future offers Christians, emerges within the framework of careful discernment or consideration in the present as described in Romans 8:18. Rasnake (2008:158) is amazed that the concept of $\lambda$ ori [considering] is found in this verse. This is a typical mathematical concept that was originally used to weigh products on a scale. It means judging after careful calculation. This consideration made Paul realise that the sufferings of the present time are not worthy of comparison with the glory which shall be revealed. It is striking that the idea of something that is poignant and weighty is utilised in the discernment of what we should do in our current sighing caused by suffering (Du Toit 2008:152).

In order to discern where we go from here, the paradox

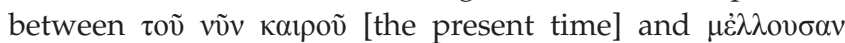
$\delta o \xi \alpha v$ [coming glory] should be carefully discerned. The coming glory (eschatology) is not something of a new possibility that does not exist within the present. The coming glory is therefore no trampoline and also not an attempt to jump on in order to escape paradoxes in the present time. This coming glory has come in Christ, and is already real and effective. By preaching the eschatological 'yet-to-come' dimension and the 'not yet' dimension of God's glory, the sermon becomes a vessel of hope. How? By acknowledging that all the paradoxes, described in Romans 8:21-29, are a reality of daily life.

Consequently, God is not imprisoned in the past, and he is no phantom of the future. Preaching with an eye on the listener's life, means telling people about the future that has already invaded the present (McMickle 2006:12). Preaching about the eschatological 'yet-but-not-yet' does not mean turning a blind eye to people's suffering. The concept of $\alpha$ лок $\alpha \alpha \delta$ окı $\alpha$ [earnest expectation or sighing] is used three times in Romans 8:18-39. The creation is eagerly looking forward to the coming glory (Rm 8:19-22), believers are eagerly looking forward (sighing) (Rm 8:23-25), and indeed the Holy Spirit joins creation and believers in this groaning ( $\mathrm{Rm}$ 8:26-27). The concept

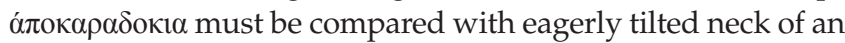
athlete that reaches for the finishing line (McMickle 2006:13). It could also indicate nostalgia or longing for something.

The three sighing movements in Romans 8:19-27 are structured in concentric circles in order to form a crescendo (Beker 1982:13). The choir of sighs are creation, creature and 
the Creator Spirit (Floor 1986:26). It is important to note that this kind of sigh does not come about because of an overwhelming despair, but because of purposeful hope and longing. It could also be said that cosmological, anthropological and pneumatological aspects join one another in a choir of symphonic sighing.

Creation sighs because of the imperfection of this age, that is, the cosmological aspect. Believers are sighing because of the longing for completion, and it can therefore also be called the pain of expectation, that is, the anthropological aspect. The Holy Spirit makes us sigh in the face of despair and fear (Vos 2007:27). The work of the Holy Spirit is described with the concept of $\sigma v v \alpha v \tau \imath \lambda \alpha \mu \beta \alpha v \varepsilon \tau \alpha$ l [helping us in our weakness]. The concept means to assist someone in supporting, to lend a hand and also to come to the aid of (Frangipani 2011:13). The sighs of the Holy Spirit are wordless or inexpressible. The indwelling Spirit is sighing in the hearts of God's children. According to Romans 8:27, this sigh in the heart of believers is also an act of

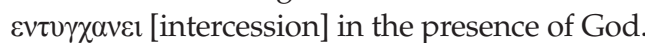

Life in a post-pandemic world utilises the two inseparable legs of sighing (due to 'not-yet') and singing of God's glory (due to 'yet'). The 'not yet' leads us to sighing about the vanity or futility of all things, while the 'yet' enables us to sing about profound hope. Vanity or futility could also denote frustration, emptiness or nothingness. Christians are assigned to or being subjected to this kind of vanity and are now sighing for deliverance. We must now admit that Romans 8:28 is frequently misunderstood. When we read that we know that in all things God works for the good of those who love him and who have been called according to his purpose, it cannot be argued that people are indemnified from suffering. Instead, God allows afflictions, but there is a certainty attached to it, namely the completeness of his promises. Unsettling and arduous circumstances are, in fact, part of the process of cooperation with the intended good in life.

\section{Perspectives derived from the sections above}

From these perspectives, one infers that God's work should not be overlooked when one preaches for suffering people. God is not bound to a mould according to which he should act. Preaching has to offer hope. A preacher, furthermore, must enable listeners with carefully calculated present realities, taking into account their own sense of nothingness and their expectations of the future. Therefore, discernment about where we go from here, where we find ourselves in the liminal position between the 'yet' and 'not yet', should receive attention. Preaching must help listeners transform their sighing into singing.

\section{A homiletical praxeology that deals with listeners feelings of angst}

Careful reflection on the hermeneutics of the present argument, results in the following elements being integrated into a homiletical praxeology for preaching to listeners in a post-pandemic world: the listeners' experiences of angst or nothingness, the value of disorienting dilemmas, preaching as a purposeful step-by-step process, the influence of remembrance, preaching as the naming of listeners' sighs and the question as to where we go from here. Each of these elements will subsequently be briefly elucidated.

\section{Preaching with visionary compassion for listeners' experiences}

Louw (2011:8) has provided a well-directed plea that should be considered for homiletic purposes around what he calls a focus on God's involvement in the predicament of human suffering. The teleology of God's concern and compassion for people's suffering cannot be ignored by homiletical praxis. Viewed from a homiletical angle, Sinndeutung should start with the idea of God's presence in the current pandemic rather than seeking reasons, blaming others and oversimplistic predictions about the end of times. Recognising the complicated experiences of listeners in all age groups, including their experience of the unusual, must enable preachers to communicate the care of God has for them, when they are looking for meaning amidst the experience of nothingness. People's angst about the present circumstances and the future should not be ignored.

Rather, it should be purposefully addressed according to the rich sources of the gospel, which deal with the idea of helping listeners discover the meaning of life in their concrete circumstances. Wright's insistence (2020) that God is working with humanity (synergeo) rather than working for humanity, is an important aspect to consider.

The notion that God is working in and through people's experiences of angst and nothingness, as caused by to the pandemic, needs attention in a homiletical praxeology. The idea that God does not stand powerless against people's angst and their suffering must be seen as pivotal. Hence, an emphasis on what listeners could practically do in their immediate environment in order to care for people who are suffering or struggling with the effects of COVID-19, should function as a praxis that enables listeners to roll up their sleeves in order to become sign-producers that are committed to erecting signposts that could help people see that life is meaningful. Preaching that deals with the importance of helping people to see, is at stake.

\section{Disorienting dilemmas evoke intriguing self- reflection on I-You relationships}

As suggested, disorienting dilemmas offer opportunities for experiencing a quest for meaning in sequential phases. People's experiences of disorienting dilemmas need a praxis that offers re-orientation.

Wilkerson (2012:34) underlines that listeners tend to lose sight of a meaningful life, because they are discouraged by the effects of the COVID-19 pandemic. Suffering tends to drag people down. Preaching must lift listeners' understanding of God, themselves, the world and their destiny. 
They should be guided to realise the essence of a worthwhile life. Rather than preach in such a manner that listeners are filled with one-sided fear about the signs of the end of times, preaching should help listeners lift their eyes to see what they could do in their immediate environment. Disorienting dilemmas certainly offer a unique opportunity to consider possibilities in the new normal of a post-pandemic world.

Rather than working with the idea of me against the dangers outside the safe haven of my home, cognisance should be taken of what listeners could possibly do to enhance the idea of a worthwhile life. One could also formulate slightly differently in saying that it is important that an attitude of $I$ owe you the interest of my care must be communicated amidst curfews and an increasing demand on social distancing. A virtual environment is therefore not the same as a blind alley. Life in a post-pandemic world offers a unique opportunity to rethink dynamic possibilities of relationship building within the seemingly new normal of a postpandemic world.

Even a life characterised by distancing from others is no excuse for sitting back and wait for the COVID-19 pandemic to disappear. Therefore, the intriguing thoughts of Marten Buber (1958:17) on the importance of the functioning of the I-Thou relationships could not be overlooked. The idea of treating people as human beings rather than dangerous infectious objects, is standing central. Buber's basic presupposition is based on the idea that human existence is, after all, interpersonal oriented and the fact that no one can say I without simultaneously saying you. People are, nevertheless, not encapsulated or imprisoned in isolation, but rather to live in perpetual relationships with people, the world and with God (cf. Morgan \& Guilherme 2012:989). The reciprocal interrelationship offers insight into exactly how preaching could offer new insights to listeners within a post-pandemic world. Rather than a onesided emphasis on the I-It relationship, the idea of I-You (Ich und $D u$ ) is more in the centre of this research. The idea of it has importance for daily living, but in seeing people as part and parcel of the it, the danger of a loss of meaningfulness will most probably emerge on the road to a mere objectification of everything in life.

This article has underlined the idea that feelings of vulnerability and angst have to be addressed in preaching. Rather than to use these feelings as an excuse for an escapist attitude, listeners should be guided to realise their unique calling in a post-pandemic world. Therefore, an attitude chance from the I-It-ness to an I-You-world seems to be the challenge, because the I-You- reality offers opportunities to have poignant encounters with people suffering from the effects of this pandemic. The virtual and online mode of functioning is indeed offering new possibilities to care for people. This kind of praxis within a post-pandemic world, where the emphasis is on the somatic (relational) characteristic, offers profound opportunities for growth. The importance of sharing memories and helping to reframe people's experiences by listening to their stories, could indeed offer opportunities to reach out.

Hence, Root (2007:107-109) rightly opts for the research of Bonhoeffer who claims that churches must invest in relational ministries. Based on these insights, it seems that the focal point of proximity to people living in a postpandemic world with an emphasis on staying away, must be seen as a challenge within a praxeology of preaching that is aligned to the importance of a relational approach.

\section{Where do we go from here? Start with the eschatological day of today}

As mentioned, there is an eschatological dimension in preaching as the communication of God's promises.

However, it was also stated that the COVID-19 pandemic has provided people with a period of introspection on where we go from here. Long (2009) distinguishes between two kinds of eschatological preaching that is aimed at avoiding the danger of jumping into the future. The first relies on a literalistic grip on biblical images and results in a gospel that is intellectually implausible, stuck in the clouds of a pious and irrelevant heaven that never touches earth. If that is our only option, the retreat into a self-contained present tense is our only choice.

The second kind of eschatology, however, allows the eschatological affirmations that 'Christ is risen!' and 'Jesus is Lord!' to exercise tension upon the present, creating the possibility of action in the world, sustained by hope.

The importance of the eschatological dimension in the 'today' should therefore not be ignored in homiletical praxeology. 'Today' could be described as a meaningful time of listening, seeing and doing.

Consequently, preaching as an act of reminding people of God's eschatological voice in Christ simultaneously takes them to God's future for his children within the here and now of their lives.

Discernment or a careful consideration of the arduous circumstances caused by the COVID-19 pandemic, has to arrive at a point where listeners are confronted with what they should do 'today'. The words of Luther come to mind, namely that even if he were to know that the world would go to pieces tomorrow, he would continue to plant his tree today. Today could be described as a meaningful and important time for listening, seeing and doing (Schöning 2016:26).

\section{Conclusion}

The argument above has outlined the contours for a homiletical praxis focused on preaching to listeners amidst 
a sense of angst or nothingness. It was underlined that preaching is meaningful; that it is not similar to saying nothing. The importance of life was also identified as a pillar of homiletical praxis. Preaching has therefore the intention to engage with the gospel and the experiences of listeners in order to re-cast what they experience in a meaningful framework. Preaching about the eschatological day of today is aimed at guiding listeners to cognisance of the fact that, in their expectation of the final day, a considerable number of vital things should be realised today. Preaching to listeners in a post-pandemic world will inevitably engage in helping them realise the importance of knowing that disorienting dilemmas are powerful moments indeed so that they can recall poignant aspects, but forget about those that are not functional for our understanding of a fulfilled life.

\section{Acknowledgements \\ Competing interests}

The author has declared that no competing interest exist.

\section{Author's contributions}

The author declares that he is the sole author of this research article.

\section{Ethical considerations}

This article followed all ethical standards for research without direct contact with human or animal subjects.

\section{Funding information}

This research received no specific grant from any funding agency in the public, commercial or not-for-profit sectors.

\section{Data availability}

The author confirms that the data supporting the findings of this study are available within the article.

\section{Disclaimer}

The views and opinions expressed in this article are those of the author and do not necessarily reflect the official policy or position of any affiliated agency of the authors.

\section{References}

Arthurs, J.D., 2018, Preaching as remembering, InterVarsity Press, Downers Grove IL.

Atkins, P., 2004, Memory and liturgy, The place of memory in the composition and practice of liturgy, Ashgate, London.

Ballard, P. \& Pritchard, J., 2006, Practical theology in action: Christian thinking in the service of church and society, Ashford Colour Press, London.

Beach, J.M., 1999, 'The real presence of Christ preaching of the Gospel: Luther and Calvin on the nature of preaching', Mid-America Journal of Theology 10(1), 89-91.

Beker, J.C., 1982, Paul's Apocalyptic Gospel: The coming triumph of God, Fortress, Philadelphia, PA.

Bowker, J.C., Bowker, M.H., Santo, J.B., Ojo, A.A., Etkin, R.G. \& Raja, R., 2019, 'Severe social withdrawal: Cultural variation in past hikikomori experiences of university students in Nigeria, Singapore, and the United States', The Journal of Genetic Psychology 180(1), 217-230. https://doi.org/10.1080/00221325.2019.1633618
Brueggemann, W., 1998, Westminster Bible Companion: Isaiah 40-66, John Knox Press, Louisville, KY.

Brueggemann, W., 2018, Interrupting silence, John Know Press, Louisville, KY.

Brueggemann, W., 2020, Virus as a summons to faith: Biblical reflections in a time of loss, grief, and uncertainty Wipf \&Stock, New York, NY.

Buber, M., 1958, I and thou, Charles Scribner's Sons, London.

Dein, S., 2020, COVID-19 and the apocalypse, Queen Mary College, London.

Du Toit, A, 2008, Romeine: Hartklop van genade, Bybelkor, Wellington.

Fiske, S.T., 2004, Social beings: A core motives approach to social Psychology, Wiley, Princeton, NJ.

Floor, L., 1986, Die evangelie van die koninkryk, NG Kerkboekhandel, Pretoria.

Frangipani, F.F., 2011, Spiritual discernment and the mind of Christ, Arrow Publications, Grand Rapids, MI.

Goldingay, S.J.K., 2020, 'Thinking with the Old Testament on the pandemic', Theology 123(3), 191-197. https://doi.org/10.1177/0040571X20920527

Grethlein, C., 2012, Praktische Theologie, De Gruyter, Berlin.

Grözinger, A., 2005, The way of experience, Gospel Works, Singapore.

Immink, F.G., 2019, 'Naming God's presence in preaching', HTS Teologiese Studies/ Theological Studies 75(4), 3, a5453. https://doi.org/10.4102/hts.v75i4.5453

Jones, D.S., 2020, History in a crisis: Lessons for COVID-19, Harvard, Cambridge.

Kandel, E.R., 2006, In search of memory: The emergence of a new science of mind, Norton, New York, NY.

Lauster, J., 2007, 'Leben. Genetischer Code/Lebensphilosophie/inneres Leben/ewiges Leben', in W. Gräb \& B. Weyl (hrsg.), Handbuch Praktische Theologie, p. 141-143, Guetersloher Verlagshaus, Gütersloh.

Long, T., 2009, Preaching from memory to hope, Westminster John Knox, Louisville, KY.

Louw, D.J., 2011, 'Ta splanchna: A theopaschitic approach to a hermeneutics of God's praxis. From zombie categories to passion categories in theory formation for a practical theology of the intestines', HTS Teologiese Studies/Theological Studies 67(3), 8 pages. https://doi.org/10.4102/hts.v67i3.1087

Louw, D.J., 2016, 'Preaching as art (imaging the unseen) and art as homiletics (verbalising the unseen): Towards the aesthetics of iconic thinking and poetic communication in homiletics', HTS Teologiese Studies/Theological Studies 72(2), 7 pages. https://doi.org/10.4102/hts.v72i2.3826

McMickle, M.A., 2006, Where have all the prophets gone? Reclaiming prophetic preaching in America, Pilgrim, Cleveland, $\mathrm{OH}$.

Mezirow, J., 1995, 'Transformation theory of adult learning', in M.R. Welton (ed.), In defense of the lifeworld, pp. 13-15, SUNY Press, New York, NY

Morgan, W.J. \& Guilherme, A., 2012, 'I and thou: The educational lessons of Martin Buber's dialogue with the conflicts of his times', Educational Philosophy and Theory 44(1), 9, 979-996. https://doi.org/10.1111/j.1469-5812.2010.00681.x

Motyer, A., 1993, The prophecy of Isaiah, Inter-varsity Press, Leicester.

Nel, M., 2018, 'Methodological: What we do is Practical Theology', in Youth Ministry: An inclusive missional approach, pp. 3-18, AOSIS, Cape Town. https://doi. org/10.4102/aosis.2018.BK83.01. (HTS Religion \& Society Series, 1)

Otto, K, 1983, The Old Testament Library: Isaiah, The Westminster Press, Philadelphia, PA. Pembroke, N., 2013, Divine therapeia and the sermon: Theocentric therapeutic preaching, Pickwick, Eugene, OR.

Rasnake, E., 2008, Romeine, CUM boeke, Vereeniging.

Ricoeur, P., 2000, La Mémoire, L'Histoire, L'Oubli, Seuil, Paris.

Root, A., 2007, Revisiting relational Youth Ministry: From a strategy of influence to a theology of incarnation, IVP Books, Downers Grove, IL

Rosenburg, C.E., 1998, 'Pathologies of progress: The idea of civilization as risk', Bulletin of the History of Medicine 72(4), 6-7. https://doi.org/10.1353/bhm.1998.0217

Sancken, J., 2019, Words that heal: Preaching hope to wounded souls, Abingdon Press, Abingdon.

Schöning, F., 2016, Hebrews and divine speech, Bloomsbury: T\&T Clark, New York, NY.

Steinmeijer, A.M., 2011, 'Ikonische Innovationen. Überlegungen zur Predigt im Horizont kultureller Lebenswelt', in T. Klie, M. Kumlehn, R. Kunz \& T. Schlag (hrsg.), Lebenswissenchaft Praktische Theologie?! Praktische Theologie im Wissenschaftsdiskurs, Band 9 (2011), pp. 253-270.

Steyn, M., Wepener, C. \& Pieterse, H.J.C., 2020, 'Preaching during the COVID-19 pandemic in South Africa: A grounded theoretical exploration', Stellenbosch Theological Journal 291, 1-19.

Taylor, S., 2019, The psychology of pandemics: Preparing for the next global outbreak of infectious disease, Cambridge Scholars Publishing, Newcastle.

Taylor, S., Landry, C., Paluszek, M., Fergus, T.A., McKay, D. \& Asmundson, G.J.G., 2020, 'Development and initial validation of the COVID stress scales', Journal of Anxiety 2(1), 1-31. https://doi.org/10.1016/j.janxdis.2020.102232

Vos, C.J.A., 2007, 'Seeing visions and dreaming dreams: The imaginative power of preaching hope', in C. Vos, L.L. Hogan \& J.H. Cilliers (eds.), Preaching as a language of hope, p. 27, Uitgeverij Boekencentrum, Zoetermeer.

Wepener, C., 2012, 'Liminality: Recent Avatars of this notion in a South African context', Scriptura 110(2), 293-307. https://doi.org/10.7833/110-0-118

Wilkerson, B.J., 2012, Helping people to think higher, Hendrickson Publishers, MA.

Wright, N.T., 2020, God and the pandemic, Zondervan, Grand Rapids, MI. 